\section{A Comparison of Temperate- climate Strawberry Production Systems Using Eastern Genotypes}

\author{
Brent L. Black, ${ }^{1}$ \\ John M. Enns, and \\ Stan C. Hokanson ${ }^{2}$
}

\begin{abstract}
Additional IndeX wOrds. Fragaria $\times$ ananassa, annual hill, plasticulture, matted row, sustainability, cover crops
\end{abstract}

Summary. Anticipating the phaseout of methyl bromide, the USDA-ARS small fruit breeding program at Beltsville, Md., discontinued soil fumigation in strawberry breeding and selection trials in the mid 1990s. To address resulting weed and pathogen pests, a modified or advanced matted row system was developed. This system uses matted row-type culture, established on raised beds with subsurface drip irrigation and organic mulch. The mulch is the residue of a killed cover crop that fixes some nitrogen and provides an economical, biodegradable mulch for suppressing weeds and reducing erosion. Since 1996, the small fruit breeding program has conducted replicated performance trials on both advanced matted row and a regional adaptation of annual hill plasticulture. Both of these systems were managed without methyl bromide fumigation or fungicide application. Data from these trials

Fruit Laboratory, Henry A. Wallace Agricultural Research Center, ARS, USDA, Beltsville, MD 20705 2350

The authors thank Gene Galletta for the foresight to initiate work on strawberry production in the absence of methyl bromide. We thank John Teasdale, Aref Abdul-Baki, and Marvin Pritts for helpful input on cover crops. We gratefully acknowledge the assistance of Ted Currier and John Bouma, Sr., of the Beltsville Farm Operations Branch for their assistance in developing and experimenting with equipment and techniques for managing cover crops on raised beds.

${ }^{1}$ To whom reprint requests should be addressed; e-mail blackb@ba.ars.usda.gov.

${ }^{2}$ Present address: Department of Horticultural Science, University of Minnesota, St. Paul, MN 55108. were used to compare advanced matted row and plasticulture for yield, fruit quality and harvest season. Yield for the two systems was genotype dependent, and the advanced matted row system had later production and slightly lower fruit quality.

$\mathrm{M}$ atted row strawberry production has long dominated the cooler production areas in North America. The matted row system has the advantages of low establishment costs that are recovered over several growing seasons, few purchased inputs, and adaptation to cooler climates (Hancock et al., 1997). However, growers in these regions have recognized the need for improving efficiency and have experimented with various modifications including the ribbon row system (Hancock and Roueche, 1983; Rotthoff, 1980).

The annual hill or plasticulture system developed in California and Florida, offers the benefits of improved weed control, early yields, larger fruit size, and ease of harvest. Efforts to expand this system to colder climates have met with some success (Fiola et al., 1995, 1997; O'Dell and Williams, 2000). However, problems with the annual system include: reliance on methyl bromide as a soil sterilant (Larson, 1996), a 50\% to $75 \%$ increase in establishment costs (Pritts and Handley, 1998) and the environmental costs of plastic manufacture and disposal. As this system is adapted to more northern climates additional problems arise, including an increased risk of frost damage, a lack of adapted cultivars, and variable yield (Hancock, 2002; Poling, 1996; Pritts and Handley, 1998).

Over the past decade, food production systems have been under examination to evaluate their sustain-ability. A number of definitions have been forwarded regarding what constitutes sustainable agriculture (reviewed by Fretz et al., 1993). In relating these various definitions to fruit production, Merwin and Pritts (1993) spelled out the following four criteria for sustainability: 1) conserving resources such as soil, water, and genetic diversity; 2) providing output sufficient to meet demand; 3 ) optimizing output per unit of input (energy, capital, labor, land); and 4) providing profits sufficient to maintain adequate living standards for farmers and to support viable rural communities. The impending loss of methyl bromide and the increasing interest in sustainability are forcing a reevaluation of strawberry production practices.

The USDA-ARS small fruit research program at Beltsville, $\mathrm{Md}$., has been developing a new strawberry cropping system, the advanced matted row, that combines attributes of both the annual hill and the matted row approaches. The perceived advantages of advanced matted row as compared to traditional matted row include 1 ) raised beds for improved root growth and ease of harvest, 2) subsurface drip irrigation for targeted placement of water and soluble fertilizer, and 3 ) the use of cover crop residue to reduce soil erosion and suppress weeds during establishment. Compared to annual hill culture, the advantages of advanced matted row include 1) eliminating the use of plastic mulch with its associated economic costs and environmental consequences, and 2 ) reduced planting costs including a 2 or 3 -fold decrease in the number of nursery plants required. The advanced matted row system may provide a sustainable alternative for improving strawberry management practices in midAtlantic and northeastern North America. Here we describe this advanced matted row system and our adaptation of the annual hill production system, and use data from 5 years of yield trials to compare the performance of these systems.

\section{Materials and methods}

The ADVANCEd MATTED ROW SYSTEM. Fields were prepared with preplant applications of micronutrient fertilizer and lime as indicated by soil tests. Raised beds spaced $5 \mathrm{ft}(1.5 \mathrm{~m})$ from center to center were formed in mid-August, with a subsurface drip irrigation line centered in each bed at a depth of 3 to 4 inches ( 7 to $10 \mathrm{~cm}$ ). Two different bed configurations were used during the course of this research. The 1997-99 results are from beds 8 inches $(20 \mathrm{~cm})$ tall and 27 inches $(70 \mathrm{~cm})$ wide, and the 2000-01 harvests were from beds 6 inches $(15$ $\mathrm{cm})$ tall and 31 inches $(80 \mathrm{~cm})$ wide. The irrigation system consisted of $\mathrm{T}$ tape plastic drip tape with emitters at a 12 -inch $(30.5-\mathrm{cm})$ spacing and a flow rate of $4.5 \mathrm{gal} / \mathrm{min} / 1000 \mathrm{ft}$ (56 $\mathrm{mL} \cdot \mathrm{min}^{-1} \cdot \mathrm{m}^{-1}$; Trickl-eez Co., Biglerville, Pa.). A winter cover crop consisting of hairy vetch (Vicia villosa), grain rye (Secale cereale) and crimson clover (Trifolium incarnatum) was seeded over the beds in late August, at 
rates of 40,70 , and $30 \mathrm{lb} /$ acre $(45,78$, and $\left.34 \mathrm{~kg} \cdot \mathrm{ha}^{-1}\right)$, respectively. When needed, overhead irrigation was used in the fall to improve cover crop establishment (Fig. la).

On about 1 April of the following spring, just before flowering, the cover crop was sprayed with glyphosate. Two weeks later the killed cover crop was cut or rolled down. Dormant bare-root strawberry plants produced in a screenhouse at Beltsville or obtained from a commercial nursery, were planted through the resulting biomass layer in late April (Fig. 1b-c). Plants were spaced 12 inches $(30 \mathrm{~cm})$ apart in a single row down the center of each raised bed, and allowed to runner and form matted rows (Fig. 1d). Each row was divided into 6-ft plots with each genotype replicated in four plots. Guard rows and plots were established at the edges of the planting. By avoiding cultivation, the cover crop residue was maintained on the soil surface to reduce erosion and suppress weeds. Some hand weeding and spot applications of herbicides were used to control remaining weeds, and blossoms were removed by hand. Some of the runners extending beyond the beds were placed back in the rows. During the establishment year, ammonium nitrate fertilizer was applied weekly through the irrigation system at a rate of $6 \mathrm{lb} \mathrm{N} /$ acre $\left(7 \mathrm{~kg} \cdot \mathrm{ha}^{-1}\right)$ for a cumulative annual rate of $100 \mathrm{lb} \mathrm{N} /$ acre (112 $\left.\mathrm{kg} \cdot \mathrm{ha}^{-1}\right)$. In the fall, rows were narrowed by application of a contact herbicide directed at the sides of the raised beds. Straw mulch was applied in late fall for winter cold protection as is commonly done in the traditional matted row system. In early March of the fruiting season, straw was removed from the tops of the beds, and placed between the beds for weed suppression. Overhead irrigation was used for spring frost protection. Starting at bloom time, the first of five weekly applications of $3.0 \mathrm{lb}$ $\mathrm{N} /$ acre $\left(3.4 \mathrm{~kg} \cdot \mathrm{ha}^{-1}\right.$ ) ammonium nitrate fertilizer was applied through the irrigation system.

ANnUAl hill Culture. The adaptation of hill or plasticulture production used at the Beltsville facility was as follows. Fields were prepared with preplant incorporation of micronutrient fertilizer and lime as per soil test recommendation. Raised beds were formed and drip irrigation placed using the bedder and drip tape arrangement as described for the advanced matted row. Beds were then mulched with 1.1-mil embossed black plastic(Trickl-eez Co.). Plug plants of each genotype were planted through the plastic mulch in mid August. Plug plants were produced in the greenhouse at Beltsville by rooting runner tips in cell packs $\left[8.5\right.$ inch $^{3}$ $\left(140 \mathrm{~cm}^{3}\right)$ rootvolume perplant]. Plants

Fig. 1. The advanced matted row production system. Raised beds are formed and subsurface drip irrigation is placed, followed by the establishment of a winter cover crop (A). The cover crop is killed with herbicide and cut down (B), dormant bare root plants are placed through the resulting biomass layer $(\mathrm{C})$, and plants are allowed to runner and form matted rows (D).

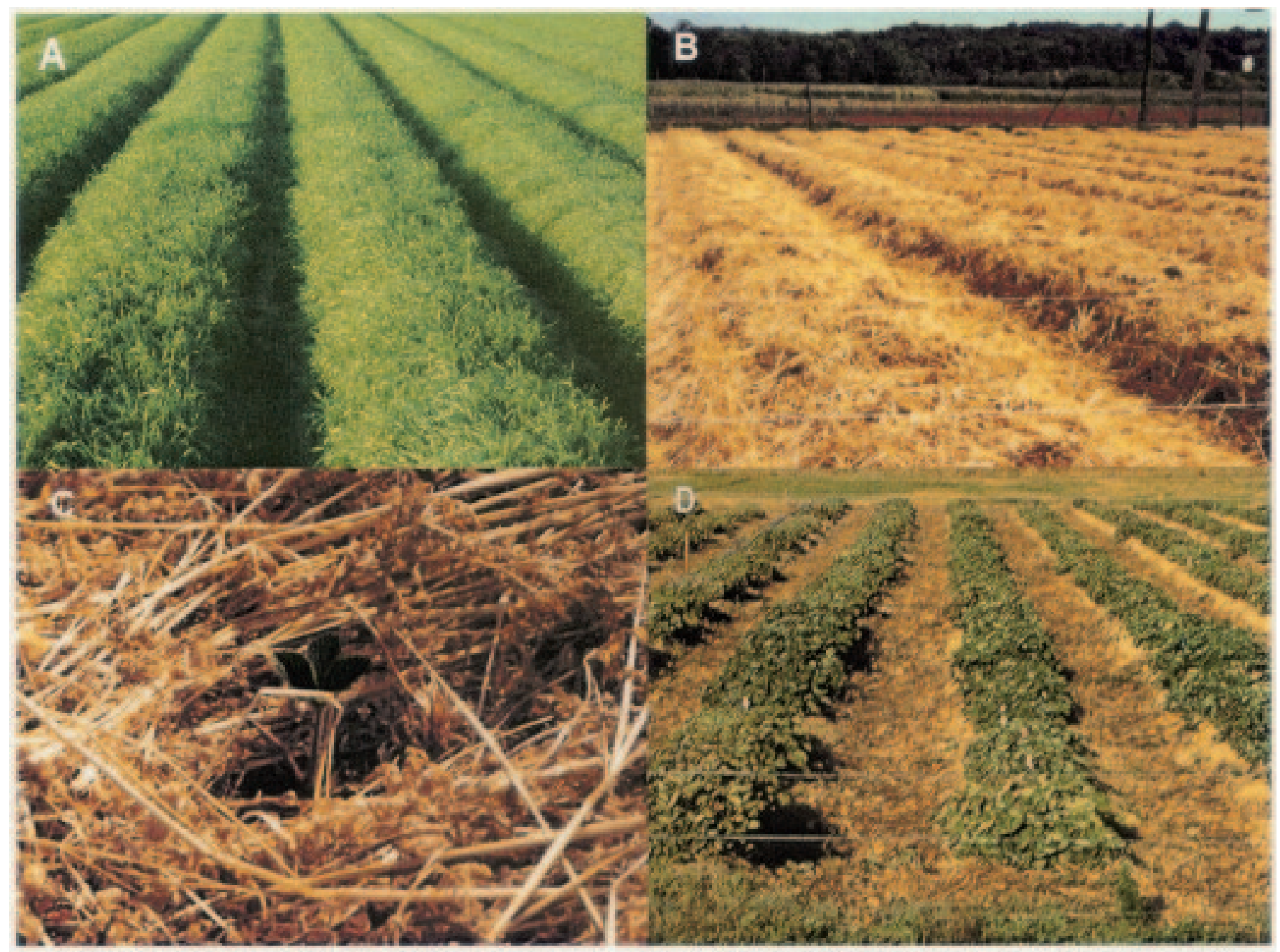


were arranged in offset double rows spaced 12 inches $(30 \mathrm{~cm})$ between and within rows, with six-plant plots for each genotype. Guard rows and plots were established at the edges of the planting. During plant establishment, five weekly applications of $14 \mathrm{lb} \mathrm{N} /$ acre $\left(15.7 \mathrm{~kg} \cdot \mathrm{ha}^{-1}\right.$ ) ammonium nitrate were applied through the irrigation system. At first growth flush the following spring, the first of four weekly applications of $3.1 \mathrm{lb} \mathrm{N} /$ acre $\left(3.5 \mathrm{~kg} \cdot \mathrm{ha}^{-1}\right)$ ammonium nitrate was applied through the irrigation system. As with the advanced matted row, straw mulch was applied in late fall for winter cold protection, removed from the beds in early March and left between the beds for weed suppression. Overhead irrigation adequately protected flowers from spring frosts in both systems, as no significant damage was noted for any of the 5 years reported here.

Both systems were established on land that had been rotated out of strawberries for at least three years. No chemical fumigants or fungicides were used in the preparation of fields, or in the strawberry plantings. Over the course of the five seasons, insecticides were used several times for mite and thrips control.

SYSTEM COMPARISON. From 1996 to 2001, the USDA-ARS small fruit breeding program at the Henry A. Wallace Agriculture Research Center in Beltsville conducted replicated yield trials of cultivars and advanced selections on both the advanced matted row system and the locally adapted version of the annual hill system just described. New replicated yield trials for both systems were established each year, and each planting was cropped for a single season, the year after planting. Fruit from both systems were harvested twice weekly, with yield, fruit size and a subjective market score recorded at each harvest. Market score was rated on a scale of one to nine, with nine representing the most marketable fruit (Galletta et al., 1995). From these data, total seasonal yield, early yield, and peak fruit weight were calculated. To determine early yield, a harvest date about 2 weeks after the start of the harvest season was arbitrarily selected for each season, and the percent of total crop harvested on or before this date was calculated. Mean fruit weight was the average over all harvests in a season. From the mean fruit weight recorded at each harvest, the maximum weight recorded within a season represents peak fruit weight, and approximates the size of primary berries (Galletta et al., 1995).

The primary objective of these plantings was to collect data for the breeding program, i.e., to evaluate genotypes for adaptability to one or the other production system, and not as a direct comparison of production systems. Therefore, in a given year, genotypes were replicated within a cropping system, but cropping systems as treatments were not replicated. However, a number of genotypes appeared concurrently in both systems, and over multiple years. Data for these genotypes were used to compare these production systems with year used as replication (replicated in time).

From yield trial records for the 1997 through 2001 harvests, data were compiled for genotypes appearing in both cropping systems concurrently, in at least 2 years. These data included two cultivars and eleven numbered selections from the Beltsville breeding program, and were analyzed as a split-plot design with cropping system as the mainplot treatment, genotype as the subplot treatment, and year as replication. This analysis was performed using the GLM procedure of SAS (1998). Means presented were calculated using the LSMEANS function, and significance of treatment differences was determined using the PDIFF option. To provide industry standards for comparison, the cultivar Chandler was grown each year in the annual hill system, and 'Earliglow' was grown in the advanced matted row system. Since these cultivars did not appear in both systems, data were not included in the statistical comparison.

\section{Results and discussion}

The advanced matted row system and a local adaptation of annual hill plasticulture were compared for productivity, season, and fruit quality using data from 5 years of replicated yield trials.

Productivity. The effect of cropping system on yield varied with genotype (Table 1), as there were significant system $\times$ genotype interactions $(P<$ $0.01)$ but no significant production system main effect on yield $(P>0.80)$. 'Allstar' and B440 showed significantly higher yields in the annual hill system

Table 1. Comparison of yields of advanced matted row and annual hill production systems with cultivars and selections from the Beltsville breeding program. Data from replicated yield trails were compiled for cultivars that appeared in both cropping systems concurrently, and over multiple years. The seasons for which data were available from 1997 to 2001 are shown in column 2. Total annual production is expressed as pounds of fruit per foot of row $(1.49 \mathrm{lb} / \mathrm{ft}=1$ $\left.\mathbf{k g} \cdot \mathbf{m}^{-1}\right)$.

\begin{tabular}{llccc}
\hline & Harvest & \multicolumn{2}{l}{ Annual yield (lb/row ft) } & \\
\cline { 2 - 3 } Genotype & year & Matted & Hill & $\boldsymbol{P}^{\mathbf{x}}$ \\
\hline 'Chandler'z & $97,98,99,00,01$ & & 1.87 & \\
'Earliglow' & $97,98,99,00,01$ & 1.87 & & \\
'Allstar' & $97,98,99,00,01$ & 2.22 & 2.81 & $* *$ \\
'Northeaster' & $97,99,00,01$ & 1.74 & 2.05 & NS \\
MDUS 5395 & $97,98,99$ & 2.67 & 2.69 & NS \\
B24 & 98,99 & 1.58 & 1.33 & NS \\
B27 & $98,99,00$ & 2.05 & 1.99 & NS \\
B28 & $98,99,00$ & 1.89 & 1.58 & NS \\
B51 & $98,99,01$ & 1.22 & 1.72 & + \\
B244-89 & $98,99,01$ & 1.82 & 1.49 & NS \\
B440 & $97,98,99,00,01$ & 1.65 & 2.49 & $* *$ \\
B443 & 98,00 & 1.91 & 1.32 & + \\
B683 & 00,01 & 1.93 & 2.07 & NS \\
B753 & 00,01 & 1.57 & 1.62 & NS \\
B793 & $99,00,01$ & 1.97 & 1.88 & NS
\end{tabular}

Analysis of variance

$P$ value for $F$ test

$\begin{array}{ll}\text { System } & 0.8634 \\ \text { Genotype } & 0.0001 \\ \text { System } \times \text { genotype } & 0.0086\end{array}$

\footnotetext{
z'Chandler' and 'Earliglow' are shown as industry standards, but were not included in calculations of means or the statistical analysis.

xince genotype $\times$ system interaction was significant at $P<0.01$, system comparisons for each genotype are indicated

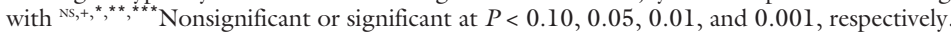


than in the advanced matted row system. Among the remaining genotypes, system differences were not significant at $P<0.05$. Interestingly, yields of B51 were $40 \%$ higher in the plasticulture system and yields of B 443 were $44 \%$ higher in advanced matted row. However, these differences were only significant at $P=0.10$, which may be due to the few seasons that these cultivars were grown (decreased replication).

The significant system by genotype interactions noted in these trials lend credence to an assumption held by some plant breeders that it should be possible to breed cultivars possessing attributes making them differentially suited to a specific production system. These attributes may include propensity for runner production or branch crown formation. For the hill system, runner production in the fruiting field is undesirable, and yields are dependent upon formation of branch crowns on the original plants. Conversely, in matted row production, yields are more dependent upon plant density, i.e. the number of daughter plants produced, than upon the formation of large multicrowned plants (Popenoe and Swartz, 1985).
Since row width and spacing varies from grower to grower, yields are presented on the basis of row length. With the bed widths and spacing used here, yields of $1.69 \mathrm{lb} / \mathrm{ft}$ of row $(2.52$ $\mathrm{kg} \cdot \mathrm{m}^{-1}$ ) translate to $15,000 \mathrm{lb} /$ acre $\left(16.8 \mathrm{t} \cdot \mathrm{ha}^{-1}\right)$ and would be the lower limit of acceptable productivity for our location, whereas yields of more than $2.0 \mathrm{lb} / \mathrm{ft}\left(3.0 \mathrm{~kg} \cdot \mathrm{m}^{-1}\right)$ or $17,800 \mathrm{lb} /$ acre $\left(20 \mathrm{t} \cdot \mathrm{ha}^{-1}\right)$ would be exceptional. The performance of 'Northeaster' was adequate in both systems, while B27 and MDUS 5395 performed extremely well in both systems. Unfortunately, MDUS 5395 was found to have poor postharvest qualities rendering it unacceptable as a potential cultivar. Although yields for 'Allstar' were significantly higher in the annual hill system, performance of this cultivar was also exceptional in the advanced matted row system.

SEASON. Black plastic mulch used in the annual hill system resulted in an earlier season (Table 2). The date of first harvest was an average of $2.9 \mathrm{~d}$ earlier in the annual hill system $(P=0.032$ for system main effect). Further, early yield was $48 \%$ of total yield on plasticulture compared to $27 \%$ for the advanced matted row (system main effect $P=$
0.009). However, these earlier yields did not translate into a longer season as indexed by the number of twice-weekly harvests (differences were not significant at $P<0.05$, Table 2 ). One suggested advantage of the annual system is an extended harvest season (Larson, 1996), however, this was not the case in our climate with these genotypes.

Fruit QualitY. The system main effects for average and peak fruit weights were not significant at $P<0.05$, but were generally higher for the annual hill system, and this difference was significant at $P=0.0649$ for average fruit weight (Table 3). Market score for fruit from the annual hill system was an average of 0.19 rating points higher than fruit from the advanced matted row system (Table 3 ). Market score is a subjective rating that takes into account such factors as fruit shape, color, incidence of disease, and overall appearance, but it is not possible to determine which of these factors contributed most to the observed differences in market score. We have observed that each system has unique problems associated with fruit quality and marketability. For example, fruit produced on plastic mulch may be cleaner and have

Table 2. A comparison of harvest season of advanced matted row and annual hill production systems. Mean date of first harvest is presented as day of year with day 1 = 1 Jan. Early yield was calculated as the percent of the total crop harvested within about the first 2 weeks of the harvest season. Length of the harvest season is indicated by the number of twiceweekly harvests.

\begin{tabular}{|c|c|c|c|c|c|c|c|}
\hline \multirow[b]{2}{*}{ Genotype } & \multicolumn{2}{|c|}{$\begin{array}{l}\text { First harvest } \\
\text { (day of year) }\end{array}$} & \multicolumn{2}{|c|}{$\begin{array}{c}\text { Early yield } \\
(\%)\end{array}$} & \multirow[b]{2}{*}{$\boldsymbol{P}^{\mathbf{z}}$} & \multicolumn{2}{|c|}{$\begin{array}{c}\text { Season length } \\
\text { (harvest no.) }\end{array}$} \\
\hline & Matted & Hill & Matted & Hill & & Matted & Hill \\
\hline 'Earliglow' & 139.4 & & 51.1 & & & 8.45 & \\
\hline 'Allstar' & 143.8 & 141.0 & 10.9 & 33.0 & $* * *$ & 9.00 & 8.65 \\
\hline 'Northeaster' & 139.0 & 136.4 & 54.3 & 69.2 & $* *$ & 8.38 & 8.10 \\
\hline $\mathrm{B} 27$ & 144.7 & 141.2 & 9.1 & 36.8 & $* * *$ & 8.88 & 8.19 \\
\hline B28 & 146.0 & 141.2 & 5.5 & 34.8 & $* * *$ & 8.79 & 8.02 \\
\hline B51 & 139.6 & 138.1 & 54.3 & 62.8 & NS & 8.21 & 7.35 \\
\hline B244-89 & 139.0 & 137.6 & 33.7 & 62.5 & $* * *$ & 9.46 & 7.69 \\
\hline B440 & 150.3 & 146.9 & 1.4 & 10.0 & + & 7.25 & 7.35 \\
\hline Mean & 142.8 & 139.9 & 27.0 & 47.8 & & 8.46 & 7.77 \\
\hline \multicolumn{8}{|l|}{ Analysis of variance } \\
\hline System & \multicolumn{2}{|c|}{0.0318} & \multicolumn{2}{|c|}{0.0093} & & \multicolumn{2}{|c|}{0.0836} \\
\hline Genotype & \multicolumn{2}{|c|}{0.0001} & \multicolumn{2}{|c|}{0.0001} & & \multicolumn{2}{|c|}{0.0015} \\
\hline System $\times$ genotype & \multicolumn{2}{|c|}{0.3414} & \multicolumn{2}{|c|}{0.0700} & & \multicolumn{2}{|c|}{0.6291} \\
\hline
\end{tabular}

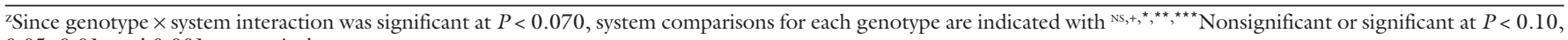
$0.05,0.01$, and 0.001 , respectively. 
decreased incidence of botrytis fruit rot (Botrytiscinerea)(Larson, 1996). However, we have observed a higher incidence of anthracnose fruit rot (Colletotrichum spp.) in the annual hill system, a finding that has been reported by others (Boudreau and Madden, 1995; Gleason et al., 1996; Madden et al., 1993; Yang et al., 1990). A genotype that is more susceptible to one of these diseases may be differentially affected by cropping system. The difference in harvest season between production systems may also result in a differential effect of adverse weather conditions (heat or rain) on a given genotype, depending on the timing of the weather event. This may have been the case for the yields of the late-season selection B440, where the use of plastic accelerated the season enough so that yield potential was reached before the unfavorably high summer temperatures arrived.

A detailed comparison of genotypes within a cropping system is beyond the scope of the current discussion, and data for 'Chandler' were not included in the statistical analysis. However, it is apparent that several eastern cultivars and selections performed as well or better than 'Chandler' in the annual hill system. Under conditions designed to mimic eastern perennial production practices, Hancock et al. (1992) found that cultivars from California did not necessarily have higher yields than eastern cultivars. Subsequently, Rariden and Shaw (1994) compared eastern and California cultivars in the California system and found that the yield advantages of California cultivars were primarily due to their adaptation to the Mediterranean climate. This may explain why 'Chandler', a California cultivar, grown in annual culture has been very successful in the milder climate of North Carolina, but results have been less consistent farther north in Maryland and New Jersey (Poling, 1996). These results, taken with our data reinforce the need to match new production systems to cultivars for each environment.

\section{Conclusions}

The data presented here represent two alternative approaches for strawberry production in colder temperate climates. These approaches are an adaptation of the annual hill system currently used in the California and Florida industries, and an improved version of the conventional matted row production system that has long dominated the colder production regions of North America. Over 5 years of cultivar and selection trials, in the absence of methyl bromide fumigation or fungicide application, the annual hill system produced an earlier crop of fruit with improved appearance when compared to the advanced matted row. The effect of cropping system on yield was genotype dependent with 'Allstar' and B440 showing significantly greater yield in the annual hill system. However, 'Allstar', B27, and MDUS 5395 all showed good productivity in both systems. Whether or not these differences in season, fruit quality, and in some cases, yield, justify the increased establishment costs and risks inherent in the annual hill system was not determined. Although data presented here provide interesting preliminary comparisons of these production systems, there are not sufficiently detailed data for economic comparisons. For example, total biological yield and subjective market score were measured for comparison of genotypes and do not accurately assess marketable yield. Additional research is underway to compare the economic and environmental costs and benefits of conventional matted row, advanced matted row and plasticulture. Since our plantings in both systems were only cropped for one year, additional research should also investigate approaches for, and the practicality

Table 3. A comparison of fruit quality characteristics of advanced matted row and annual hill production systems. Market score is a subjective rating based on general appearance and marketability, with 9 representing the most marketable. Mean fruit weight is the season average and peak fruit weight is the maximum mean weight recorded among harvest dates within a season $(454 \mathrm{~g}=1 \mathrm{lb})$.

\begin{tabular}{|c|c|c|c|c|c|c|}
\hline \multirow[b]{2}{*}{ Genotype } & \multicolumn{2}{|c|}{$\begin{array}{l}\text { Market score } \\
\text { (range 1-9) }\end{array}$} & \multicolumn{2}{|c|}{ Avg fruit size (g) } & \multicolumn{2}{|c|}{ Peak fruit size (g) } \\
\hline & Matted & Hill & Matted & Hill & Matted & Hill \\
\hline 'Chandler' & & 6.78 & & 12.6 & & 20.4 \\
\hline 'Earliglow' & 6.29 & & 9.4 & & 16.2 & \\
\hline 'Allstar' & 6.79 & 6.83 & 14.4 & 14.7 & 24.7 & 25.5 \\
\hline 'Northeaster' & 6.70 & 6.93 & 13.0 & 14.9 & 23.3 & 28.2 \\
\hline MDUS 5395 & 6.64 & 6.93 & 15.2 & 15.6 & 26.8 & 28.8 \\
\hline B24 & 6.97 & 7.19 & 13.7 & 15.0 & 24.2 & 24.7 \\
\hline $\mathrm{B} 27$ & 6.57 & 6.53 & 14.8 & 16.8 & 27.9 & 31.4 \\
\hline B28 & 6.63 & 6.36 & 14.5 & 16.6 & 27.7 & 33.1 \\
\hline B5l & 6.37 & 6.75 & 12.2 & 13.9 & 21.9 & 26.6 \\
\hline B244-89 & 7.05 & 7.19 & 12.2 & 13.4 & 20.5 & 19.1 \\
\hline $\mathrm{B} 440$ & 7.34 & 7.32 & 13.6 & 15.3 & 23.8 & 28.8 \\
\hline B 443 & 6.75 & 6.88 & 10.7 & 13.9 & 18.9 & 25.0 \\
\hline B683 & 6.76 & 7.18 & 12.5 & 13.3 & 20.1 & 20.6 \\
\hline B753 & 6.65 & 7.13 & 10.9 & 14.7 & 19.7 & 23.9 \\
\hline B793 & 6.72 & 7.12 & 14.9 & 16.3 & 31.6 & 30.7 \\
\hline Mean & 6.76 & 6.95 & 13.3 & 14.9 & 23.9 & 26.6 \\
\hline
\end{tabular}

Analysis of variance

\begin{tabular}{llll}
\hline System & 0.0419 & 0.0649 & 0.1870 \\
Genotype & 0.0021 & 0.0082 & 0.0001 \\
System $\times$ genotype & 0.8977 & 0.9440 & 0.6031 \\
\hline
\end{tabular}


of, renovating and cropping these systems for multiple years.

The impending loss of methyl bromide as a soil fumigant is forcing a reevaluation of strawberry production practices. As we research ways to advance or alter strawberry production in North America, we should consciously evaluate the impacts of changes not only on yield and profitability, but also on conserving environmental resources, improving the viability of small-farm strawberry production, and the potential benefits to consumers and society (Nonnecke and Dewitt, 1995; Pritts, 2002). Adaptations of the annual hill or plasticulture system are already being explored to improve the economic sustainability of cold-climate strawberry production. Improvements in the matted row production system may provide an alternative to plasticulture for maintaining profitability while minimizing impact on the environment.

\section{Literature cited}

Boudreau, M.A. and R.D. Madden. 1995. Effect of strawberry density on dispersal of Colletotrichum acutatum by simulated rain. Phytopathology 85:934-941.

Fiola, J.A., C. O'Dell, and J. Williams. 1997. Cool climate strawberries fare well on plasticulture. Fruit Grower. (May):41-42.

Fiola J.A., R.J. Lengyen, and D.A. Reichert. 1995. Planting density and date affect productivity and profitability of 'Chandler', 'Tribute' and 'Tristar' in strawberry plasticulture. Adv. Strawberry Res. 14:49-52

Fretz, T.A., D.R. Keeney, and S.B. Sterrett. 1993. Sustainability: Defining the new paradigm. HortTechnology 3:118-126.

Galletta, G.J., J.L. Maas, J.M. Enns, A.D. Draper, J.A. Fiola, J.C. Scheerens, D.D. Archbold, and J.R. Ballington, Jr. 1995. 'Delmarvel' strawberry. HortScience 30:1099-1103.

Gleason, M.L., B.L. Leininger, G.R. Nonnecke, D.R. Lewis, and J.J. Obrycki. 1996. Spray strategies to control anthracnose fruit rot in day-neutral strawberries. Fungicide Nematicide Tests 51:89.

Hancock, J.F. 2002. The strawberry in North America: Past lessons and future promise, $\mathrm{p}$. 6-10. In: S.C. Hokanson and A.R. Jamieson (eds.). Strawberry research to 2001. ASHS Press, Alexandria, Va.

Hancock, J.F., B.L. Goulart, J.L. Luby, and M.P. Pritts. 1997. The strawberry matted row: Practical cropping system or dated anachronism? Adv. Strawberry Res. 16:1-4.

Hancock, J.F., S.C. Hokanson, P.W. Cal- low, M. Sakin, K. Haghighi, and J.A. Flore. 1992. Performance of Californian and eastern U.S. strawberry cultivars under conditions mimicking eastern production systems. J. Amer. Soc. Hort. Sci. 117:991995.

Hancock, J. and J. Roueche. 1983. A comparison of ribbon and matted row strawberry culture. Adv. Strawberry Prod. 2:7-8

Larson, K.D. 1996. Challenges for annual strawberry production systems. Proc. IV North Amer. Strawberry Conf. p. 155-161.

Madden, L.V., L.L. Wilson, and M.A. Ellis. 1993. Field spread of anthracnose fruit rot of strawberry in relation to ground cover and ambient weather conditions. Plant Dis. 77:861-866.

Merwin, I.A. and M.P. Pritts. 1993. Are modern fruit production systems sustainable? HortTechnology 3:128-136.

Nonnecke, G.R. and J.R. DeWitt. 1995. Sustainable strawberry production: A new model for growers and researchers. Proc. IV North Amer. Strawberry Conf. p. 193-197.

O'Dell, C.R. and J. Williams. 2000. Hill system plastic mulched strawberry production guide for colder areas. Va. Tech. Coop. Ext. Publ. 438-018.

Poling, E.B. 1996. Challenges for annual strawberry production systems in cool climates. Proc. IV North Amer. Strawberry Conf. p. 162-170.

Popenoe, J. and H.J. Swartz. 1985. Yield component comparison of strawberry plants grown in various cultural systems. Adv. Strawberry Prod. 4:10-14.

Pritts, M. 2002. Growing strawberries, healthy communities, strong economies and clean environments: what is the role of the researcher? Acta Hort. 567:411-417.

Pritts, M. and D. Handley. 1998. Strawberry production guide for the northeast, midwest and eastern Canada. N.E. Reg. Agr. Eng. Serv., Ithaca, N.Y.

Rariden, J.M. and D.V. Shaw. 1994. Performance of North American strawberry cultivars under conditions mimicking California production systems. J. Amer. Soc. Hort. Sci. 119:1034-1038

Rotthoff, W. 1980. Challenging practices, systems and thoughts for the ' 80 's, p. 7782. In: N.F. Childers (ed.). The strawberry: Cultivars to marketing. Hort. Publ., Gainesville, Fla

SAS Institute. 1998. Version 6.12. SAS Inst., Cary, N.C.

Yang, X., L.L. Wilson, L.V. Madden and M.A. Ellis. 1990. Rain splash dispersal of Colletotrichum acutatum from infected strawberry fruit. Phytopathology 80:590595.

\section{Genetic}

Improvement of

Virginia Pine

Planting Stock

for Christmas

Tree Production

in South Carolina

\author{
Jenny Knoth, ${ }^{1}$ \\ John Frampton, ${ }^{1}$ and \\ Ray Moody ${ }^{2}$
}

Additional index words. Pinus virginiana, choose and cut, heritability, gain, correlation, quality, crown density, retail value

Summary. Twenty open-pollinated families from a virginia pine (Pinus virginiana) seed orchard in South Carolina were planted and managed as Christmas trees at three sites. Retail value and related traits were assessed once the tests reached marketable size (4 years in the field). All traits assessed (except survival) proved to 1 ) be under a moderate degree of genetic control (family mean heritability $\mathbf{0} \mathbf{0 . 6 8}$ for retail value) and 2) have a large range among open-pollinated family means $(\$ 11.42 /$ tree to $\$ 22.00 /$ tree, retail value) suggesting that they will response well to the traditional tree improvement approach of selection, breeding and testing. The retail value of the best five families tested averaged an increase of $\$ 3.47 /$ tree or $20.7 \%$ more than the average. At a $6 \times 6 \mathrm{ft}$ $(1.8 \mathrm{~m})$ spacing $[1,210$ trees/acre $(2,990$ trees/ha) $]$, these families would produce an increase in revenue of almost \$4,200/acre (\$10,387/ha). Much of this increase in value is a result of reducing the cull rate from $14.5 \%$ to $8.1 \%$. Survival, height, crown density and straightness of these five families also exceeded the average of the 20 families tested.

The authors gratefully acknowledge Christmas tree growers Dale Taylor and Tom Wright for their maintenance and culture of the field trials. The Nursery and Tree Improvement Program of the South Carolina Forestry Commission and the Agricultural Research Service of North Carolina State University contributed funding to this research.

${ }^{1}$ North Carolina State University, Department of Forestry, Box 8002, Raleigh, NC 27695-8002.

${ }^{2}$ Nursery and Tree Improvement, South Carolina Forestry Commission, P.O. Box 21707, Columbia, SC 29221. 